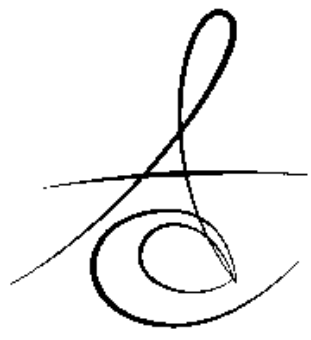

\title{
ORTODONTİDE KULLANILAN MALZEMELERİN SİTOTOKSİSİTESİNİN DEĞERLENDİRİLMESİ
}

\author{
EVALUATION OF THE CYTOTOXICITY OF MATERIALS USED IN \\ ORTHODONTICS
}

\author{
Dt. Cafer Sadık KARAKAŞ* Doç. Dr. Elçin ESENLİK*
}

Makale Kodu/Article code: 1975

Makale Gönderilme tarihi: 21.11.2014

Kabul Tarihi: 19.03.2015

\section{ÖZET}

Hastaların güvenli tedavisini sağlamak için, dental materyallerin sitotoksisitesini tanımlamak çok önemlidir. Sitotoksisite, çeşitli makromoleküllerin sentezlenmesinin engellenmesi sonucu hücrenin fonksiyonlarında ve yapısında hasar meydana gelmesidir. Sitotoksisite mekanizmaları; oksidatif stres ve korozyon odaklıdır. Oksidatif stres mekanizması serbest radikal üretimi ve DNA hasarı sonucu mutasyonlar ile, korozyon ise metal iyon salınımı ile etki göstermektedir. Ortodontide en sık kullanılan materyaller; ark telleri, braketler, rezin adezivler ve bonding ajanlar, mini implantlar, akrilik rezinler, elastomerik maddeler, cam iyonomer simanlar, lehim alaşımlar, magnetler ve invisalign apareylerdir. Bu materyallerin biyo-uyumlulukları metal kompozisyonuna, ısıl işlem görüp görmediğine, üretim yöntemine veya polimerizasyon derecesine bağlıdır. Bu nedenle ortodontik malzemeler sitotoksisite ve iyon salınımı açısından iyi değerlendirilmeli ve sitotoksik özellikleri azaltmak için bazı önlemler alınmalıdır.

Anahtar Kelimeler: Ortodontik materyal, biyouyumluluk, sitotoksisite

\section{GİRIŞ}

Gelişen teknoloji ile birlikte ortodontik malzemelerin çeşitliliği de artmış ve alternatif birçok sistem geliştirilmiştir. Bu sistemlerin kullanımında hastaların güvenli tedavisini sağlamak için, dental materyallerin biyo-uyumluğunu ve olası sitotoksisitesini tanımlamak çok önemlidir. Sitotoksisite, moleküler olaylar sonucu çeşitli makromoleküllerin sentezlenmesinin engellen-

\section{ABSTRACT}

The defining the cytotoxicity of dental materials is of great important to ensure the safe treatment of patients. Cytotoxicity is defined as damaging the cell structure and function as a result of inhibition of the synthesis of various macromolecules. Cytotoxicity mechanisms are focused on oxidative stress and corrosion. Mechanisms of oxidative stress show effects as mutations resulted from free radicals production and DNA damage; mechanism of corrosion exhibits metal ion release as well. The most common materials used in orthodontics are; arch wires, brackets, adhesives and resin bonding agents, mini implants, acrylic resins, elastomeric materials, glass ionomer cements, solder alloys, magnets and Invisalign appliances. Biocompatibility of these materials depends on the metal composition,whether they are exposed to heat process, production method of them or the degree of polimerization of it. Therefore orthodontic materials should be considered in terms of cytotoxicity and ion release and certain measures should be taken for decreasing cytotoxic properties.

Key-words: Orthodontic materials, bio-compatibility, cytotoxicity.

mesi ve buna bağlı olarak hücrenin fonksiyonlarında ve yapısında belirgin hasarlar meydana gelmesi olarak tanımlanır. ${ }^{1}$ Sitotoksisite mekanizmaları daha çok 1) oksidatif stres ve 2) korozyon üzerinde odaklanmaktadır. Oksidatif stres mekanizması serbest radikal üretimi ve DNA hasarı sonucu mutasyonlar ile, korozyon ise metal iyon salınımı ile etki göstermektedir. ${ }^{2}$

* Süleyman Demirel Üniversitesi Diş Hekimliği Fakültesi Ortodonti AD 
Biyolojik sistemlerde elektron alıcı moleküller serbest radikaller olarak adlandırıırlar. Hücre metabolizması veya eksojen fiziksel veya kimyasal kaynakların faaliyeti sonucu oluşan reaktif oksijen türleri canı hücrelerde bulunan serbest radikaller olarak adlandırımaktadır. ${ }^{3}$ Bunlar çeşitli biyolojik reaksiyonlarda önemli roller üstlenirken, aynı zamanda birçok hastalığın patogenezinde etken oldukları belirtilmektedir. Serbest radikaller elektron alma özelliklerinden dolayı birçok organın veya dokunun yapısını veya fonksiyonunu bozabilirler. Vücuttaki serbest radikallerin artması ya da antioksidanların azalması sonucu, serbest radikaller normal makromoleküllerle etkileşebilmekte ve doku harabiyeti meydana getirebilmektedir. Bu harabiyet, hücrelerde DNA hasarına sebep olarak gerçekleşmekte ve bu durum da hücresel DNA tamir mekanizmalarıla giderilmektedir. ${ }^{4}$ Yani bu defans mekanizmaları reaktif oksijen türlerinin artmış üretimi sonucu baskılanırsa, karsinogenezis mekanizmasına bağlantılı olarak oksidatif stres oluşmaktadır. ${ }^{3}$ Günümüzde teknolojik ürünlerin hızla artması ve bu ürünlerin kullanımı ile vücuttaki (hatta oral kavitedeki) oksidatif stresin arttığını bildiren birçok çalışma bulunmaktadır. ${ }^{5,6}$ Bunların yanı sıra ortodontik materyallerde de sıklkkla kullanılan demir, krom, bakır, kobalt gibi bazı ağır metallerin direkt olarak serbest radikal üretebildiği; nikelin de indirekt olarak serbest radikal üretebildiği bilinmektedir.

Sitotoksisite oluşumundaki mekanizmalardan "Korozyon" ise metalin temel özelliklerinde kayba yol açan elektrokimyasal bir süreçtir. Oral kavitede korozyonu sıcaklık, tükürük miktarı ve kalitesi, tükrük $\mathrm{PH}^{\prime}$ ', tükrükteki protein miktarı, plak miktarı, yiyecek ve sıviların fiziksel ve kimyasal özellikleri ve genel ve oral sağlık durumları gibi faktörler etkilemektedir. Oral kavite kendine özgü yapısıyla materyallerin sitotoksisitesini bir dereceye kadar önleyebilmekte veya artırabilmektedir. Örneğin tükürük, elektron ve iyon iletimi için elektrolit gibi davranır; PH, ISI, enzimatik ve mikrobiyal aktivitelerin azalıp çoğalmasında rol oynar ve besin ve içeceklerle ağız ortamına taşınan çeşitli kimyasallar korozyon iletkenidir. Her metal alaşımın doğal heterojenitesi ve diğer alaşımlarla kullanımı, mikroyüzey düzensizliği, uygulanan kuvvetler ve teller ve braketler arasındaki sürtünme de korozyon sürecinde etkilidir. ${ }^{7}$

Korozyonun tiplerinden çukur korozyon daha çok braket ve tellerde görülmekte, çatlak korozyonu genelde elastomerik ligatürlerin brakete uygulanmasında görülmektedir ve metal iyon farkından ve çatlak ve çevresindeki oksijen konsantrasyonundan dolayı oluşmaktadır. Asıl kaynağı, oksijeni tüketen ve krom oksit pasif tabakasının yenilenmesini engelleyen plak formasyonu ve mikrobiyal flora ürünleridir. Aşındırma korozyonu ise, metalik telin braket slotunda kayarken ara yüzeylerde soğuk kaynak kısımları içerir ve kontak noktalarının kırılması ile sonuçlanır. ${ }^{8}$ Görüldüğü gibi korozyonun oluşmasında sadece materyal değil, oral kavitenin özellikleri ve hijyen alışkanlıkları da önemli faktörler olarak karşımıza çıkmaktadır.

Korozyon gösteren başlıca metaller nikel, krom ve kobalttır. ${ }^{9}$ Braketler, bantlar, ark telleri gibi ağız içi sabit ortodontik apareyler, değişik yüzdelerde nikel, krom veya kobalt içermektedir. Nikel, tip IV geçikmiş hipersensitivite immün cevabı olan allerjik kontak dermatitin en yaygın nedenidir. Bayanlarda daha yüksek sıklıkta olmak üzere toplumun \%4 ile 28'i arasında görüldüğü bildirilmiştir. ${ }^{10,11}$ Sabit ortodontik uygulama ile günlük ortalama 40 mikrogram nikel salıımı olmaktadır. Buna rağmen, ortodontik hastalarda rapor edilmiş nikele bağlı kontak dermatit vakası birkaç tanedir. ${ }^{12}$ Nikel güçlü bir immünolojik uyaran olmasına rağmen, hastaların immünolojik tolerans geliştirebildikleri düşünülmektedir. Oral mukozada allerjik bir reaksiyon oluşturmak için, deri allerjisine kıyasla daha fazla antijen gereklidir. Bunun dışında, krom ve kobalt iyonlarının hipersensitivite, dermatit ve astıma sebep olabildiği de belirtilmiştir. ${ }^{13}$

Literatürde sitotoksisitesi incelenen ortodontik materyaller; ark telleri, braketler, rezin adezivler ve bonding ajanlar, mini implantlar, akrilik rezinler, elastomerik maddeler, cam iyonomer simanlar, lehim alaşımlar, magnetler ve invisalign apareyler olarak sayılabilir. Bu materyaller, alt başıklar halinde aşağıda incelenmiştir.

\section{Ark Telleri}

Ark tellerinin biyo-uyumlulukları büyük ölçüde metal kompozisyonuna bağlı olarak belirlenmektedir. ${ }^{14}$ Ark tellerinin yapımında kullanılan demir, krom, bakır, kobalt ve nikel gibi bazı ağır metaller serbest radikaller üretmektedir. ${ }^{3,15}$ Günümüzde kullanılan ortodontik ark telleri sıklıkla \%15-54 arası nikel, \%20-30 arası krom ve \%40-60 arası kobalt içermektedir. Nikel, çeliğin kübik yapısını korumak, dayanıklıı̆ı, esnekliği ve korozyon direncini arttırmak için eklenmektedir. Krom ise, korozyon direncini etkilemekte, krom içeriği 
arttıkça direnç de artmaktadır. Krom içeren alaşımlar, elektrokimyasal olarak oluşan pasif film sebebiyle çabuk korozyona uğramazlar. Karmaşık ve ince pasif film, havadaki agresif iyonlara karşı koruma sağlar ve korozyonu önler. ${ }^{16}$

Konuyla ilgili çalışmalarda, paslanmaz çelik tellerin sitotoksik ve nörotoksik olduğu ${ }^{17}, \mathrm{NiTi}$ tellerin paslanmaz çeliklerden daha az sitotoksik olmakla beraber, en az sitotoksite gösteren telin Bioforce Sentalloy olduğu belirtilmektedir. ${ }^{11}$ Diğer bir çalışmada ise, paslanmaz çelik tellerin biyouyumluluğunun en yüksek, nikel-titanyum tellerin ise en düşük olduğu bulunmuş; ancak tüm ark tellerinin oksidatif stres kaynağı olduğu belirtilmiştir. ${ }^{9}$

Klinikte ortodontist, paslanmaz çelik telde loop, heliks veya ark bükümleri gibi manipülasyonlar yaptığında, materyaldeki internal stres çok yüksek seviyelere ulaşır ve stres giderici ısıl işlem gerektirir. İşlem, en iyi şekilde düşük sıcaklıkta uzun zamanda yapılmalıdır. Yüksek sıcaklıklara çıkıldığında, tel yüzeyinde stabil olmayan bir oksit film tabakası oluşmakta ve daha fazla korozyon ve yüzey pürüzlülüğüne sebep olduğu bildirilmektedir. ${ }^{18}$ Paslanmaz çelik tellere vakumlu bir ortamda fırın soğutmalı ısı işlemi uygulandığında, en yüksek korozyon direncine ve düşük iyon salınımı derecesine sahip olduğu belirtilmiştir. ${ }^{16}$

Ayrica ortodontik teller steril olmayan bir koşulda ve paketinde otoklavlanabilir ifadesiyle teslim alınmaktadır. Otoklavlama sırasında ark tellerinin kalitesinin ve karakteristiklerinin etkilenebildiği ve oksidasyona daha eğilimli hale geldiği de rapor edilmiştir. ${ }^{4}$ Ancak konuyla ilgili yapılmış olan çalışmalarda, tellerin zamanla deforme olmasının ve $\mathrm{PH}$ değişimleri gibi klinik koşulların yeteri kadar taklit edilemediği belirtilmiştir. Genel olarak biyolojik dokularla veya sıvılarla kontak halinde yerleştirilen materyaller için, $\mathrm{PH}$ dalgalanmaları veya sıcaklık değişiklikleri gibi lokal mikro-çevresel faktörler tarafından oluşturulan organometalik bileşik oluşumları alaşımın korozyon miktarını arttırabilmektedir. ${ }^{19} \mathrm{Bu}$ nedenle bu konuyla ilgili yeni çalışmalara intiyaç duyulmaktadır.

\section{Braketler}

\section{Paslanmaz çelik braketler}

Paslanmaz çelik, ortodontik braketlerde de sıklıkla kullanılmaktadır. Materyalin temel avantajı, düşük maliyeti ve iyi mekanik özellikleridir. Bununla birlikte, bu materyallerin korozyona eğilimi olmakta ve metal iyon salınımı yapmaktadırlar. Metalik braketlerin üretiminde frezeleme, döküm ve metal enjeksiyon kalıplama yöntemleri kullanılmaktadır. Hangi üretim yönteminin daha az sitotoksik olduğu konusunda görüş birliği olmasa da, lehimlenmiş parçaları bulunan braketlerin daha sitotoksik olabileceği düşünülmektedir. ${ }^{20}$ Paslanmaz çelikteki gümüş bazlı lehim alaşımları genel olarak bakır ve çinko salınımına yol açan bir galvanik akım oluşturmaktadır. Son dönemlerde, altın bazı ı lehim materyali tanıtılmıştır. Altın biyolojik olarak uyumlu olsa da, bu yeni materyal de galvanik akıma sebep olmakta ve aynı zamanda paslanmaz çeliğin ayrışmasına öncülük etmektedir. Yapılan bir çalışmada, tek parça enjeksiyon kalıplama ve iki parça lehimli yöntemle yapılan paslanmaz çelik ortodontik braketlerin yapay tükürük solüsyonunda yüzey morfolojisi incelenmiş ve tek parça enjeksiyon kalıplama braketlerin daha düşük yüzey pürüzlülüğüne sahip olduğu, daha az por içerdiği ve daha yüksek korozyon direnci gösterdiği belirtilmiştir. ${ }^{21}$

Daha önce paslanmaz çelik ark tellerinde de bahsedildiği gibi, metal brakete uygulanan Isıl işlem alaşımın yüzey korumasını değiştirmektedir. Eğer çelik yüksek sıcaklıklara kadar ısıtılırsa, krom karbit çökeltisi oluşur ve intragranüler korozyona duyarlı hale gelerek yapının zayıflamasına sebep olur. Nikel salınımının incelendiği bir çalışmada, en fazla nikel salınımının geri dönüşüme uğramış braketlerden (kumlanıp, steril edilip, tekrar kullanılan), en az salınımın nikel içermeyen braketlerden olduğu ve nikel alerjisi gösteren hastalar için ideal olduğu belirtilmiştir. ${ }^{10}$ Çalışmada ağız ortamı taklit edilse de, tükrük miktarı, kalitesi ve ph'ı, plak miktarı, besinlerin kimyasal ve fiziksel özellikleri gibi faktörler göz ardı edilmiştir.

\section{Titanyum braketler}

Titanyum, yakın bir zamanda metalik ortodontik braketlere alternatif olarak sunulmuştur. Titanyumun tercih edilme nedenleri; kanitlanmış biyo-uyumu, artmış korozyon direnci olması ve alerjik olmamasıdır. ${ }^{22}$ Uzun süredir kullanılan dental implantlar, artroplasti parçaları, plaklar ve vidalar gibi titanyum içerikli biyomedikal uygulamalar da bunu desteklemektedir.

Günümüzdeki titanyum braketler, saf titanyum veya titanyum alaşımı şeklindedir. Özellikle vanadyumun tehlikeli biyolojik etkileri, alternatifler üretmek üzere klinisyenleri araştırmalara sevketmiştir. Böylece, yeni nesil titanyum alaşımlar ortaya çıkmıştır. ${ }^{19}$

\section{Polikarbonat braketler}

Polikarbonat rezinler, biyo-uyumlulukları, uygun

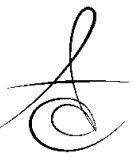


mekanik özellikleri ve olağanüstü estetikleri yüzünden dental materyal olarak ve estetik ortodontik braketlerin yapımında sıklıkla kullanılmaktadır. İlk üretimlerde doldurucu kullanımamış polikarbonatlardan ortodontik braket üretimi; fazla distorsiyon, renk değiştirme ve lekelenme yüzünden başarısız olmuştur. İstenmeyen özellikleri azaltmak ve suya karşı direnci arttırmak için, yeni cam partikülleri veya cam-fiber desteklenmiş, metalle sağlamlaştııımış slot içeren materyaller tanıtılmıştır. ${ }^{23}$ Birçok plastik estetik braketin üretiminde, bisfenol-A (BPA) temel hammaddedir. BPA yapISI büyük ve sert bir zincir oluşturarak, daha fazla rijidite, dayanım ve bozulmaya daha az hassasiyet göstermektedir. Dahası, ISI ve darbe dayanımı, mükemmel optik özellikleri, çatlamadan plastik deformasyona uğraması, kolay şekillendirme ve ısıyla şekillendirme kapasitesi sebebiyle üretimde kullanılmaktadır. Buna rağmen BPA'nın, kuvvetli deri allerjeni olması ve zararlı hormonal etkiler göstermesi gibi dezavantajları bulunmaktadır. ${ }^{24}$ Konuyla ilgili bir çalışmada, polikarbonat braketlerin oksidatif stres mekanizmasını aktive ettiği ve fiber-cam güçlendirilmiş polikarbonat braketlerin sitotoksik etkiye sahip olduğu belirtilmiştir. ${ }^{23}$

\section{Seramik braketler}

Seramik braketlerle ilgili yapılan çalışmalarda, bu braketlerin ağız ortamında kimyasal olarak inert olduğ ${ }^{25}$ ve monokristalin seramik braketlerin iyi biyouyum gösterdiği belirtilmektedir. ${ }^{26}$

\section{Rezin Adezivler ve Bonding Ajanlar}

Ortodontik rezin adezivler organik monomer matriks ve inorganik doldurucu komponent olmak üzere iki ana komponentten oluşurlar. Bununla beraber organik matriks ve doldurucular arasındaki bağı kuvvetlendiren, polimerizasyonu başlatan ve polimerizasyon hızını ayarlayan komponentler de içermektedir. Ortodontik rezin adezivler, serbest radikal mekanizması ile polimerize olmaktadır. Bu işlem sırasında, adezivin organik monomerleri polimer ağa dönüşmektedir. Tümüyle polimerize rezinlerin zararlı biyolojik etkilerinin olmadığı belirtilmekle birlikte, ortodontik bonding rezinlerin tamamen polimerizasyonun olanaksız olduğu da rapor edilmiştir. ${ }^{27,} 28$

Rezin adezivlerden sızıntı, rezinin yapılanmasında ve fonksiyonel olduğu sırada olmak üzere iki zamanda görülebilir. Yapılanma sırasında, sızıntı daha hızıdır. Restorasyonun fonksiyonel olduğu ağız içi periyottaki sızıntı materyalin bozulmasına bağlıdır. ${ }^{29}$ Sızıntının önemi, potansiyel tehlikeli bir ürün olan formaldehitin oluşmasıdır. ${ }^{30}$ Rezin adezivlerden sızıntı gösteren komponentler, monomer BisGMA, komonomer TEGDMA, kamforokinon ve diğer ürünlerdir. En çok rastlanılan komponent TEGDMA iken, BisGMA nadiren solüsyonda rastlanır. ${ }^{31}$

Rezin bazlı materyallerden salınan kimyasal komponentlerin sistemik alımı, uçucu partiküllerin akciğerlerden inhalasyonu, gastrointestinal yol ve dentini geçerek pulpaya difüzyonu olmak üzere 3 ana yol izlemektedir. Ortodontide kimyasal partiküllerin sistemik alımına sebep olabilecek en riskli durumlar, braketlerin ağızda yaklaşık 2 yıl kalması, lingual retainerların yıllar boyunca kalması ve debonding işlemi sayılabilir. ${ }^{23}$

Ağız ortamı sadece braketlerin çevresel kenarlarıla ilişkilidir ve ortalama 150-250 mikrometre arasındadır. Eğer adeziv çok inceyse, aktivatör-adeziv oranı artarak sistemde daha fazla rezidüel monomer kalmasına sebep olur. Diğer taraftan, adeziv kalınlığındaki artış yetersiz aktivatör penetrasyonuna sebep olacağından homojen olmayan polimerizasyon paterni üreterek, sitotoksisiteyle sonuçlanacaktır. ${ }^{32}$ Polimerizasyon derecesi, bir rezin adezivin ne kadar polimerize olduğunu ifade eder ve monomer moleküllerin ve materyale ulaşan ışık ve enerjinin özelliklerine bağlıdır. Polimerizasyon derecesi arttıkça, rezin adevizin çözünürlüğü ve bozulması azalmaktadır.

Rezin adezivlerde sıklıkla kullanılan bisfenolA'nın sitotoksik etkileri güncel bir konudur. Epoksi rezin, üretilmiş en kuvvetli endüstriyel deri allerjeni olarak tanıtılmakta ve bisfenol-A da, bu grup kimyasallardan sayılmaktadır. BPA grubu içinde, moleküler ağırlığı 340 olan komponent insan derisine en hassas olandır. Geçmiş on yılda, BPA'nın kızlarda erken puberte, erkeklerde feminen özelliklerin artışı, kadınlarda artmış göğüs kanseri riski, erkeklerde artmış prostat kanseri riski, kalsiyum akışını tetikleyerek prolaktin salınımına neden olmak, hiperglisemi ve insülin toleransı gelişimi, reaktif oksijen ürünlerinin artışı gibi insanlar üzerinde birçok hormon ilişkili etkiye sebep olduğu gösterilmiştir. ${ }^{33}$

Yapılan çalışmalara göre, tüm ortodontik adezivler sitotoksiktir ve inert olmaktan uzaktır. Dual-cure sistemler, kimyasal ve ışıkla serteleşen adezivlere göre daha sitotoksik bulunmuştur. ${ }^{34}$ BPA salınımının tam temaslı ışıklamada bile görülebileceği; bu mesafe arttıkça polimerizasyon derecesinin düştüğü ve BPA salınımında artış olduğu belirtilmiştir. ${ }^{35}$ 


\section{Primerler}

Ortodonti pratiğinde primerlerin rolü, diş ve kompozit materyal arasında adeziv bir arayüzey sağlamasıdır. Ortodontik primerler su, aseton veya etanol gibi çözücüler içinde seyreltilmiş monomer karışımıdır. Yapılan bir çalışmaya göre, hidrofobik ortodontik primerler, hidrofilik olanlara göre daha sitotoksiktir ve ortodontik primerler, reaktif oksijen türleri üretimine neden olmaktadır. ${ }^{36}$ Farklı ortodontik primerlerin değerlendirildiği başka bir çalışmada da, primerlerin hücre metabolizmasının işleyişini bozdukları ve tek katmanlı kültürlerde hücre ölümüne sebep oldukları bildirilmektedir ${ }^{37}$.

\section{Akrilik Rezinler}

Ortodontide akrilik rezinlerin sitotoksisitesi, aparey yapımı ve kullanımından dolayı çok önemlidir. Ayrıca bireysel kaşık yapımında, yarık dudak-damakı hastaların erken ortopedik apareylerinde ve ortognatik cerrahi için splint yapımında da kullanımaktadır. Akrilik rezinler Isıly polimerize olan, fotopolimerize olan, otopolimerize olan ve mikrodalga ile polimerize olan olarak sınıflandırılsa da, düşük maliyeti ve kullanım kolaylığı yüzünden otopolimerize rezinler ortodontide en yaygın kullanılandır. ${ }^{38}$

Polimetilmetakrilatların temel komponenti metakrilik asidin metil esteri olsa da, ortodonti ve protetik diş hekimliğinde birçok farklı komponent de kullanılmaktadır. Isıla polimerize olan protez akriliği genellikle polimetilmetakrilattan oluşurken, ışıkla veya mikrodalga ile polimerize olan akrilik materyaller polimetilmetakrilat ve üretan dimetakrilattan oluşmaktadır. Kimyasal veya otopolimerize olan akrilikler ise redoks reaksiyonu ile tetiklenmektedir. ${ }^{39}$ Avantajlarına rağmen, polimetilmetakrilat oral mukozada irritasyona, enflamasyona ve allerjik reaksiyonlara sebep olabilir. Ayrıca, akrilik materyallerin potansiyel olarak toksik, karsinojenik, mutajenik ve östrojenik olduğu belirtilmektedir. ${ }^{40}$

Akrilik rezinlerin fiziksel özelliklerini ve biyouyumluluğunu en üst düzeye çıkarmak için yeterli polimerizasyon çok önemli bir faktördür. Metilmetakrilat, yumuşak dokuların sağlığını tükrük ve oral kavite yoluyla veya komşu dokularla direkt temas ile etkileyebilmektedir. Metilmetakrilat bir allerjen olarak görülmektedir ve eritema, yanma şikayeti, ödem, fissürler, nekroz, ağrı ve bazı sistemik reaksiyonlar gibi olumsuz durumlar oluşturabilmektedir. ${ }^{39}$ Konuyla ilgili bir çalışmada, akrilik rezinlerin sitotoksik etkisinin polimerizasyondan sonraki ilk 24 saatte daha fazla olduğu ve zamanla azaldığı belirtilmektedir. Akrilik rezin ne kadar ıslanırsa, sitotoksik etkisinin o kadar az olacağı da rapor edilmiştir. ${ }^{41}$

\section{Mini-İmplantlar}

Mini-implantların biyo-uyumluluğu ve sitotoksisitesi önemlidir, çünkü bu materyaller direkt olarak periodontal dokulara ve alveoler kemiğe yerleştirilmektedir. Mini-implantlardan salınan metalik iyonlar oral mukoza, gingiva ve alveoler kemik gibi komşu dokularda enflamatuar veya nekrotik reaksiyon oluşturabilir.

Titanyum, dental implantlarda en sık kullanılan materyaldir. İmplant materyali olarak saf titanyum uygun mekanik özellikleri ve mükemmel biyouyumluluğu ile çok yaygın kullanılmaktadır. Buna rağmen, saf titanyumun yorgunluk dayanımı düşüktür. Aynı zamanda, saf titanyum mini-implantlar yerleştirme ve yerinden çıkarma işlemlerinde başarısız olabimektedir. Bu dezavantajın üstesinden gelmek için titanyum-alüminyum-vanadyum alaşımının kullanımı önerilmiştir. ${ }^{42}$ Ancak vücut sıvılarındaki korozyon eğiliminden dolayı, vanadyum ve alüminyum iyonları potansiyel toksik sayılmaktadır. Bu metalik iyonların klinik başarııızık, osteolizis, kutanöz allerjik reaksiyonlar, hipersensitivite ve karsinogenezis gibi yan etkilere sebep olabildiği belirtilmiştir. ${ }^{43}$

Vanadyum, birçok memeli hücresinde bulunan ve alımı en çok besinlerle olan bir elementtir. Vanadyum, makrofajlar ve fibroblastlar için sitotoksik olabilir, çeşitli demir proteinleri tarafından bağlanabilir, lokal veya sistemik reaksiyonları tetikleyebilir, hücre proliferasyonunu engelleyebilir ve karaciğer, böbrekler, kemik ve dalakta birikebilir. Üriner boşaltım, vanadyum için başııca eliminasyon yoludur. Ancak titanyum alaşımlı ortodontik mini-implantlardaki vanadyum salııımının, besin ve içecek yoluyla günlük alımdan çok daha az olduğu bildirilmiştir. ${ }^{44}$ Konuyla ilgili diğer çalışmalarda da, mini-implantlardan vanadyum salınımının minimal olduğu ve maksimum seviyede bile toksik seviyeye ulaşmadığı, kısıtlı kullanım süresinden dolayı endişe verici bir durum olmadığı belirtilmektedir. ${ }^{22,44}$

\section{Elastomerik Maddeler}

Lateksin allerji reaksiyonlara sebep olabileceği bilinmektedir. Ortodontik elastiklerle alakalı çoğu allerjik reaksiyonlar, küçük veziküllerin ve akut ödemin ortaya çıkması ve kaşıntı ve yanma problemleri ile karakterizedir. Doğal lateks allerjisi birçok protein

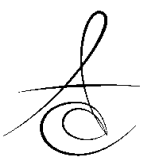


çeşidinin varlığı ve ortodontik elastikleri kaplayan pudranın bu proteinler için taşıyıcı işlevi görmesi sonucu gelişmektedir. Bu nedenle lateks olmayan elastiklerin gelişimi, büyük klinik önem kazanmaktadır. ${ }^{45}$ Allerjik reaksiyonlar dışında, şişlik, stomatitis, eritematöz oral lezyonlar, solunum reaksiyonları ve anafilaktik şokun da görülebileceği rapor edilmiştir. ${ }^{46}$

Literatürde, renkli latekslerin fabrikasyon sürecinde katılan renklendiricilerin düşük de olsa toksik etkisinin olduğu vurgulanmıştır. ${ }^{47}$ Başka bir çalışmaya göre, potansiyel sitotoksik elastiklerin kullanımındaki en büyük riskin, elastiklerden salınan maddelerin zamanla toksik madde birikmesine sebep olup hastalık oluşturabilecek olmasıdır. ${ }^{48}$

\section{Cam İyonomer Simanlar}

Cam iyonomer simanlar, asit salabilen floroaluminasilikat cam tozları ile akrilik asit veya akrilik asit- asit kopolimer karışımının reaksiyonu sonucu oluşurlar. Cam iyonomer simanlardaki gelişmelerin ışığında, konvansiyonel cam iyonomer simanlara hidrofilik monomerler ve polimerizasyon başlatıcılar eklenerek rezin modifiye cam iyonomer simanlar elde edilmiştir. ${ }^{49}$ Ortodontide kullanılan bazı cam iyonomer simanların, yüksek konsantrasyonlarda DNA hasarı ve hücre ölümü yoluyla sitotoksik ve genotoksik etkilere sebep olduğu bildirilmektedir. ${ }^{50}$ Yapılan başka bir çalışmada, Vitremer ve Vitrabond'un hücrelerde güçlü sitopatik etkilere sebep olduğu belirtilmektedir. Bu simanlar yerine, düşük sitotoksisiteye sahip Fuji IX Gp ile Ketac-Molar'ın kullanımı önerilmektedir. ${ }^{51} \mathrm{Bu}$ görüşü destekleyen diğer bir çalışmada da, diğer cam iyonomer simanlara göre daha fazla florid salınımı yapan Fuji Plus ve Vitrebond'un insan dental pulpa kök hücrelerine yüksek derecede toksik olduğu belirtilmektedir. ${ }^{52}$

\section{Lehim Alaşımları}

Birçok alaşım, paslanmaz çelikle benzer bileşimdedir ve yüz maskesinin, molar bantların ve braketlerin fabrikasyon sürecinde çeşitli lehimlerde kullanılmaktadır. En sık kullanılan lehim alaşımlar genellikle gümüş, bakır ve çinkodan oluşmaktadır. Gümüş lehimdeki iyonlar oral kaviteye salınabilir ve akut veya kronik olarak toksik değişikliklere sebep olabilmektedir. Kadmiyum, bakır, gümüş ve çinko akciğerlerde, prostat bezinde ve böbreklerde karsinojenik potansiyele, hematopoetik, üriner ve sindirim sisteminde değişikliklere sebep olduğu için potansiyel tehlikeli kimyasallar olarak nitelendirilmektedir. Bu yüzden, diğer alternatif alaşımlar ve lazer lehimleme önerilmektedir. ${ }^{53}$ Yapılan bir diğer çalışmada, gümüş lehimli bantlarla lehimsiz bantlar karşılaştırılmış ve gümüş lehimli bantların daha sitotoksik ve genotoksik olduğu belirtilmiştir. ${ }^{54} \mathrm{Bu}$ nedenle bant seçimlerinde gümüş lehim kullanılmayanlar tercih edilebilir.

\section{Magnetler}

Magnetlerin ortodontideki kullanımı; dişlerin intrüze veya ekstrüze edilmesi, dişlerin ark teli boyunca hareket ettirilmesi, fonksiyonel apareyler ve ortopedik ekspansiyon olmak üzere çok çeşitlilik göstermektedir. Magnetlerin uzun dönem klinik uygulaması oral kavitede korozyon eğilimi yüzünden kısıtlanmaktadır. Ağız içinde magnetlerin korozyonunu önlemek için kaplama, plakalama, sarmalama gibi işlemler denenmiştir. Bazı vakalarda, magnetler parilen, proplast veya akrilik ile kaplanmış, paslanmaz çelikle veya titanyumla plakalanmıştır. ${ }^{55}$ Literatürde, magnetlerin klinik kullanım öncesi hermetik olarak kaplandığında sitotoksisite açısından bir sakıncası olmadığını belirten ve kaplamanın salınımı engellemede etkisinin minimal olduğunu bildiren çalışmalar mevcuttur. ${ }^{55,56}$ Bununla birlikte magnetlerin korozyonunu önlemek için yapılan parilen kaplamanın ağız içi kuvvetlere dayanıklı olmadığı da bildirilmektedir. ${ }^{57}$ Yapılan kaplamanın ağız içinde dayanıklı olmaması ve hermetik kapatmanın bozulması da sitotoksisite riskini arttırabilmektedir.

\section{Invisalign Apareyler}

Ortodontide, BPA salınımı için olası adaylar arasında plastik materyaller, adezivler, polikarbonat braketler ve alignerlar sayılabilir. Bu alignerlar aşamalı diş hareketi sağlamak için günlük 22 saat olmak üzere yaklaşık 2 hafta boyunca oral kavitede kalmaktadır. Konuyla ilgili bir çalışmada, Invisalign apareylerin sitotoksisite ve östrojenite göstermediğini ve kısa klinik kullanım süresi ve polieter üretan yapıda olmalarının bunda etkili olabileceğini vurgulamışlardır. ${ }^{58}$ Diğer bir çalışmada, etanol solüsyonuna atılan kullanılmış Invisalign apareylerinden monomer salınımı gözlenmemiştir. ${ }^{59}$ Yakın zamanda yapılan bir çalışmada ise, tuzlu su solüsyonunda Invisalign plastiğinin epitelyal hücrelerin adezyonunda, membran geçirgenliğinde ve canlılığında değişikliğe sebep olarak, gingivada lokalize veya sistemik allerjiye sebep olabileceği belirtilmiştir. Daha önceki çalışmalarda Invisalign apareylerinin sitotoksik olmadığı belirtilirken, güncel çalışmalar bu konunun tartışmaya açık olabileceğini göstermektedir. $^{60}$ 
Klinik koşullarda alınabilecek bazı önlemlerle materyallerin sitotoksisitesi azaltılabilir veya maruz kalma oranı değiştirilebilir. Bu önlemlere genel olarak bakılacak olursa:

* Duyarlı hastalarda, nikel içeriği azaltılmış veya nikel olmayan braketler ve ark telleri tercih edilmelidir.

* Ark teline Isıl işlem uygularken korozyonu arttırmamak için yüksek ısıdan kaçınılmalı ve uzun sürede düşük ısı kullanılmalıdır.

* Yüksek polimerizasyon dereceli rezin adezivler tercih edilmelidir. Işınlama meziyal, distal, okluzal ve gingival bölgelerden 10'ar saniye boyunca yapılmalıdır. Eğer diş rotasyonlu veya malpoze ise, ilave ışınlama düşünülebilir.

* Özellikle adezivin oral dokularla yakın temasta olduğu alanlarda, polimerizasyon sonrası braket tabanı çevresindeki fazla adeziv kaldırılmalıdır.

* Debonding sonrası BPA salınımını azaltmak için pomza tozunun kullanımı tavsiye edilmektedir.

* Braket ve retainer bonding işleminden sonraki bir saat süresince, sızıntı yapan monomerlere maruz kalmayı azaltmak için hastalar ağızlarını çalkalamalıdır.

* Renkli latekslerin düşük de olsa toksik etkisi olduğundan, hassas bireylerde renksiz veya şeffaf olanları tercih edilmelidir. Yine bu bireylerde lateks içermeyen elastomerik materyaller kullanılmalıdır.

* Akrilik rezinlerdeki metilmetakrilat, hastalar ve dental çalışanlar için özellikle allerjiye ve hipersensitiviteye sebep olabileceğinden, tam polimerizasyondan emin olunmalı ve havadar bir yerde çalışılmalıdır.

\section{SONUÇ}

Sitotoksisite konusunda yapılan çeşitli ve kapsamlı araştırmalara rağmen, birçok ortodontik materyalin sitotoksisik özelliğinde görüş birliğine varılamamıştır. Yine de tedavi süresince uzun dönem ağız ortamında kalan ortodontik malzemeler sitotoksisite ve iyon salınımı açısından iyi değerlendirilmeli ve hastanın özelliklerine göre uygun materyal seçimi yapılmalıdır. Sabit tedavi elemanlarının iyon salınımı, diyetle alınan miktarın çok altında kalsa da, uzun süreli az salınımın da dokularda biyolojik etki oluşturabileceği unutulmamalıdır. Özellikle immünolojik duyarlılı̆a yatkın kişilerde, malzemelerin sitotoksisite dereceleri göz önünde bulundurularak seçilmelidir.

\section{KAYNAKLAR}

1. Murray PE, García Godoy C, García Godoy F. How is the biocompatibilty of dental biomaterials evaluated? Med Oral Patol Oral Cir Bucal 24. 2007;12(3):258-66.

2. Mitchell $R$, Cotran R. Cell injury, adaptation and death. In: Kumar V, Cotran R, Robbins S, editors. Robbins basic pathology. 7th ed. Philadelphia: W. B. Saunders; 2003. p. 4-11.

3. Pilger A, Rüdiger HW. 8-Hydroxy-2'deoxyguanosine as a marker of oxidative DNA damage related to occupational and environmental exposures. Int Arch Occup Environ Health 2006;80:1-15.

4. Spalj S, Zrinski MM, Spalj VT. In-vitro assesment of oxidative stress generated by orthodontic archwires. Am J Orthod Dentofacial Orthop 2012;141:583-9.

5. Çiftçi ZZ, Kırzıoğlu Z, Nazıroğlu M. Effects of prenatal and postnatal exposure of Wi-Fi on development of teeth and changes in teeth element concentration in rats : Wi-Fi $(2.45 \mathrm{GHz})$ and teeth element concentrations. Biol Trace Elem Res. 2015;163:193-201.

6. Çiğ B, Nazıroğlu M. Investigation of the effects of distance from sources on apoptosis, oxidative stress and cytosolic calcium accumulation via TRPV1 channels induced by mobile phones and Wi$\mathrm{Fi}$ in breast cancer cells. Biochim Biophys Acta. 2015;10-4C:2-8.

7. Hafez HS, Selim EM, Kamel Eid FH. Cytotoxicity, genotoxicity, and metal release in patients with fixed orthodontic appliances: a longitudinal in-vivo study. Am J Orthod Dentofacial Orthop. 2011;140(3):298-30.

8. Matasa CG. Characterization of used orthodontic brackets. In: Eliades G, Eliades T, Brantley WA, Watts DC, editors. In vivo aging of dental biomaterials. Chicago, Quintessence: 2003. p. 12539.

9. Sfondrini MF, Cacciafesta V, Maffia E. Nickel release from new conventional stainless steel, recycled, and nickel-free orthodontic brackets: An in vitro study. Am J Orthod Dentofacial Orthop 2010;137:809-15. 
10. Hwang C, Shin J, Cha J. Metal release from simulated fixed orthodontic appliances. Am J Orthod Dentofacial Orthop 2001;120:383-91.

11. Bishara S E, Barret R D, Selim M I. Biodegradation of orthodontic appliances Part II. Changes in the blood level of nickel. Am J Orthod Dentofacial Orthop 1993;103:115-9.

12. Trombelli L, Virgili A, Corazza M, Lucci R. Systemic contact dermatitis from an orthodontic appliance. Contact Dermatitis 1992; 27:259-60.

13. Vreeburg KJJ, von Blomberg $M$, Scheper RJ. Induction of immunological tolerance by oral administration of nickel and chromium. J Dent Res 1984;63:124-8.

14. Staerkjaer L, Menne T. Nickel allergy and orthodontic treatment. Eur J Orthod 1990;12:2849.

15. Torreilles J, Guerin M C, Slaoui-Hasnaoui A. Nickel (II) complexes of histidyl-peptides as Fentonreaction catalysts. Free Radical Research Communications 1990;11:159-66.

16. Oh K, Kim K. Ion release and cytotoxicity of stainless streel wires. Eur J Orthod 2005;27:53340.

17. David A, Lobner D. In vitro cytotoxicity of orthodontic archwires in cortical cell cultures. Eur J Orthod 2004;26: 421-6.

18. Gjerdet N R, Hero $H$. Metal release from heattreated orthodontic archwire. Acta Odont Scand 1987;45:409-14.

19. Gioka C, Bourauel C, Zinelis S, Eliades T, Silikas N, Eliades G. Titanium orthodontic brackets: structure, composition, hardness and ionic release. Dent Mater 2004;20:693-700.

20. Wataha JC, Hanks CT, Craig RG. In vitro effects of metal ions on cellular metabolism and the correlation between these effects and the uptake of the ions. J Biomed Mater Res 1994;28:427-33.

21. Chen C, Ou K, Wang W. Variation in Surface Morphology and Microstructure of 316L Biomedical Alloys Immersed in Artificial Saliva. J Exp Clin Med 2013;5:30-6.

22. Sernetz F. Titanium and titanium alloys in orthodontics. Quintessence Int 1995;21:615-26.

23. Kloukos D, Taoufik E, Eliades T. Cytotoxic effects of polycarbonate-based orthodontic brackets by activation of mitochondrial apoptotic mechanisms. Dental Materials 2013;29:35-44.
24. Artham T, Doble M. Biodegradation of aliphatic and aromatic polycarbonates. Macromolecular Bioscience 2008;8:14-24.

25. Kusy R, Whitley J. Degradation of plastic polyoxymethylene brackets and the subsequent release of toxic formaldeyde. Am J Orthod Dentofacial Orthop 2005;127:420-7.

26. Retamoso LB, Luz TB, Marinowic DR. Cytotoxicity of esthetic, metallic, and nickel-free orthodontic brackets: Cellular behavior and viability. Am J Orthod Dentofacial Orthop 2012;142:70-4.

27. Chung $\mathrm{KH}$ : The relationship between composition and properties of posterior resin composites. J Dent Res 1990;69:852-6.

28. Gül P, Akgül N. Kompozit materyallerin biyouyumluluğu hakkında literatür derlemesi. Atatürk Üniv Diş Hek Fak Derg. 2013;7:78-86.

29. Demirci T, Gürbüz T. Dental rezin kompozitlerin sitotoksisitesi: Bir in vitro çalışma. Atatürk Üniv Diş Hek Fak Derg 2014;24:10-5.

30. Hanks CT, Strawn SE, Wataha JC. Cytotoxic effects of resin components on cultured mammalian fibroblasts. J Dent Res 1991;70:1450-5.

31. Rahiotis C, Kakaboura A, Loukidis M, Vougiouklakis G. Curing efficiency of various types of light-curing units. Eur J Oral Sci 2004;112:89-94.

32. Ahrari F, Afshari JT, Poosti M. Cytotoxicity of orthodontic bonding adhesive resins on human oral fibroblasts. Eur J Orthod 2010;32:688-92.

33. Eliades T, Hiskia A, Eliades G. Assessment of bisphenol-A release from orthodontic adhesives. Am J Orthod Dentofacial Orthop 2007;131:72-5.

34. Jagdish N, Padmanabhan S, Chitharanjan AB. Cytotoxicity and degree of conversion of orthodontic adhesives. Angle Orthod 2009; 79: 1133-8.

35. Sunitha C, Kailasam V, Padmanabhan S. Bisphenol $A$ release from an orthodontic adhesive and its correlation with the degree of conversion on varying light-curing tip distances. Am J Orthod Dentofacial Orthop 2011;140:239-44.

36. D'Anto V, Spagnuolo G, Schweikl H. Effect of Nacetyl cysteine on orthodontic primers cytotoxicity. Dental Materials 2011;27:180-6.

37. D’Anto V, Spagnuolo G, Polito I. In vitro cytotoxicity of orthodontic primers. Prog Orthod 2009;10:4-11. 
38. Öztürk F, Malkoc S, Ersöz M. Real-time cell analysis of the cytotoxicity of the components of orthodontic acrylic materials on gingival fibroblasts, Am J Orthod Dentofacial Orthop 2011;140:243-9.

39. Geurtsen W. Polymethylmethacrylate resins. In: Schmalz G, Arenholt-Bindslev D, editors. Biocompatibility of dental materials. Berlin and Heidelberg, Germany: Springer; 2009. p. 255-67.

40. Graber TM, Vanarsdall RL Jr, Vig KWL. Orthodontics. Current principles and techniques. 4th ed. St Louis: Elsevier; 2005. p. 374-9.

41. Sheridan PJ, Koka S, Ewoldsen NO, Lefebvre CA, Lavin MT. Cytotoxicity of denture base resins. Int J Prosthodont 1997;10:73-7.

42. Doruk C, Ozturk F, Ozdemir H, Nalcaci R. Oral and nasal malodor in patients with and without cleft lip and palate who had undergone orthodontic therapy. Cleft Palate Craniofac J 2008;45:481-4.

43. Malkoç S, Öztürk F, Çörekçi B. Real-time cell analysis of the cytotoxicity of orthodontic miniimplants on human gingival fibroblasts and mouse osteoblasts. Am J Orthod Dentofacial Orthop 2012;141:419-26.

44. Morais L, Serra G, Muller C, Andrade L. Titanium alloy mini-implants for orthodontic anchorage: Immediate loading and metal ion release. Acta Biomaterial 2007;3:331-9.

45. Santos R, Pithon M, Mendes G. Cytotoxicity of intermaxillary orthodontic elastics of different colors: An in vitro study. J Appl Oral Sci. 2009; 17:326-9.

46. Weiss ME, Hirshman CA. Latex allergy. Can J Anaesth. 1992;39:528-32.

47. Holmes J, Barker MK, Walley EK, Tuncay OC. Cytotoxicity of orthodontic elastics. Am J Orthod Dentofacial Orthop 1993;104:188-91.

48. Schmalz G. Use of cell cultures for toxicity testing of dental materials: advantages and limitations. J Dent. 1994;22:6-11.

49. Lewis J, Nix L, Schuster G, Lefebvre C, Knoernschild K, Caughman G. Response of oral mucosal cells to glass ionomer cements. Biomaterials 1996;17:1115-20.

50. Angelieri F, Joias RP, Bresciani E. Orthodontic cements induce genotoxicity and cytotoxicity in mammalian cells in vitro. Dent Res J (Isfahan) 2012;9:393-8.
51. Costa CA, Hebling J, Godoy FG. In vitro cytotoxicity of five glass-ionomer cements. Biometarials 2003;24:3853-8.

52. Kanjevac T, Milovanovic M, Volarevic V. Cytotoxic effects of glass ionomer cements on human dental pulp stem cells correlate with fluoride release. Med Chem 2012;8:40-5.

53. Freitas MPM, Oshima HMS, Menezes LM. Release of toxic ions from silver solder used in orthodontics: An in-situ evaluation. Am J Orthod Dentofacial Orthop 2011;140:177-81.

54. Gonçalves T, Menezes L, Trindade C. Cytotoxicity and genotoxicity of orthodontic bands with or without silver soldered joints. Mutation Research 2014;762:1-8.

55. Ahmad K, Drummond J, Graber T. Magnetic strength and corrosion of rare earth magnets. Am J Orthod Dentofacial Orthop 2006;130:11-15.

56. Darendeliler M, Mandurino M. Clinical application of magnets in orthodontics and biological implications: a review. Eur J Orthod 1997;19:43142.

57. Noar J, Wahab A, Evans R. The durability of parylene coatings on neodymium-iron-boron magnets. Eur J Orthod 1999;21:685-93.

58. Eliades $T$, Pratsinis $H$, Athanasiou AE. Cytotoxicity and estrogenicity of Invisalign appliances. Am J Orthod Dentofacial Orthop 2009;136:100-3.

59. Schuster S, Eliades G, Zinelis S. Structural conformation and leaching from in vitro aged and retrieved Invisalign appliances. Am J Orthod Dentofacial Orthop 2004;126:725-8.

60. Premaraj T, Simet S, Beatty M. Oral epithelial cell reaction after exposure to Invisalign plastic material. Am J Orthod Dentofacial Orthop 2014;145:64-71.
Yazışma Adresi
Doç. Dr. Elçin Esenlik
Süleyman Demirel Üniversitesi
Diş Hekimliği Fakültesi
Ortodonti AD Çünür/Isparta
Tel: 02462118807
Cep: 05327181482
e-mail: elcinesenlik@gmail.com 